\title{
Study of Complex Vertebral Malformation in Repeat Breeder and Anoestrous Cows
}

\author{
S.B. Khade*, M.P. Sawane, V.D. Pawar, M.M. Chopade, \\ R.D. Deshmukh and S.J. Komatwar \\ Bombay Veterinary College, Parel, Mumbai-12, India \\ *Corresponding author
}

\begin{abstract}
A B S T R A C T
\end{abstract}
\section{Keywords \\ CVM, PCR-RFLP \\ Article Info \\ Accepted: \\ 04 July 2018 \\ Available Online: \\ 10 August 2018}

\begin{abstract}
The aim of this study was to identify the Complex Vertebral Malformation (CVM) in repeat breeder and anoestrous animals in Maharashtra state region. Total 102 animals of HF crossbred, Dangi, Gaolao and Non- descript were screened from field and cattle dairy farm. CVM is a hereditary recessive disorder in Holstein cattle which have a significant economic impact on dairy cattle breeding worldwide. Fifty repeat breeder and fifty-two anoestrous animals blood DNA were extracted by traditional method. Genotyping was performed by using PCR-RFLP analysis with the help of PstI restriction enzyme. In the performed study all animals were normal for Complex Vertebral Malformation.
\end{abstract}

\section{Introduction}

Genetic disorders are genetic problem which caused by one or more abnormalities in the genome. In animals an important effect is the production of animals becomes less or loss of performance. Now a day it is possible to detect the genetic disorders on the molecular basis.

There are number of autosomal recessive disorders like Complex Vertebral Malformation (CVM), Factor XI deficiency (FXID), Bovine Leucocyte Adhesion Deficiency (BLAD), Deficiency of Uridine Monophosphate synthase (DUMPS) and Bovine Citrullinamia are Holstein Friesian breed specific.
CVM is autosomal recessive inherited disorder in Holstein breed which causes intrauterine mortality leading to repeat breeding. CVM is characterised by misshapen of cervical, thoracic and lumbar vertebrae regions, ribs abnormality as well as rotation of fetlock joint.

The occurrence of CVM was first time described in 2000 in Holstein calves. The molecular basis of CVM is missense mutation from $G$ to $T$ at nucleotide position 559 of bovine solute carrier family 35 member 3 (SLC35A3) gene. It results in V180F amino acid substitution of Golgi-resident UDP-Nacetylglucoseamine transporter enzyme which causes abnormal somitogenesis and impaired development of fetal axial skeleton. To 
diagnose the CVM several molecular methods like PCR-RFLP, PCR-PIRA, AS-PCR, CRSPCR and SSCP have been developed and proved useful.

\section{Materials and Methods}

In the present study total 102 blood samples of HF crossbred, Dangi, Gaolao and Nondescript were collected from field and some were from dairy farm in Maharashtra state. In that the fifty-two animals were repeat breeder and fifty were anoestrous cows.

Aseptically the blood samples were subjected to extract the DNA by Phenol Chloroform method. The extracted DNA was checked for its purity by electrophoresis using 0.8 per cent agarose gel for 30 minutes at $90 \mathrm{~V}$ and assessed under UV spectrometer. The quantification was also checked by Nano drop. The OD ranging 260/280 of DNA which was between 1.7 and 2.0 used for PCR-RFLP analysis.

The final volume of $25 \mu \mathrm{l}$ prepared for the CVM PCR protocol containing 1X PCR buffer

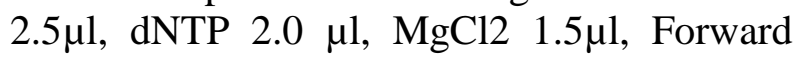
primer $0.5 \mu l \quad$ (5'CACAATTTGTAGGTC TCACTGCA3') Reverse primer $0.5 \mu 1$ (5'CGATGAAAAAGGAACCAAAAGGG3)

(Yathish et al., 2011) Taq DNA Polymerase $0.2 \mu 1$, Template DNA 1.0 $\mu 1 \quad(\sim 100 \quad \mathrm{ng})$, Nuclease free water $16.8 \mu \mathrm{l}$. The PCR reaction included the following steps:

Initial Denaturation at $94^{\circ} \mathrm{c}$ for 2 minutes, Denaturation $94^{\circ} \mathrm{C}$ for $45 \mathrm{secs}$, Annealing temperature $59.7^{\circ} \mathrm{c}$ for $45 \mathrm{sec}$ repeat cycle for 40 times and final extension for $10 \mathrm{~min}$ at $72^{\circ} \mathrm{c}$. The PCR products were resolved by electrophoresis using 1.7 per cent agarose gel in $1 \mathrm{X}$ TAE buffer. The amplified PCR products were confirmed by gel electrophoresis. The PCR product were digested with PstI restriction enzyme. The total $15 \mu \mathrm{l}$ volume for the digestion containing PCR product $10.0 \mu \mathrm{l}$, Restriction enzyme 1.0 $\mu 1$, RE buffer $1.5 \mu \mathrm{l}$ and Nuclease free water $2.5 \mu \mathrm{l}$. The mixture was incubated at $37^{\circ} \mathrm{c}$ for 4 hours in the water bath.

After the digestion the products were electrophoresed on 2.5 per cent agarose gel. The band size was judged by comparing with molecular marker and available literatures references.

\section{Results and Discussion}

The quality of DNA was checked by electrophoresis and quantity of DNA was checked by Nano drop. The Complex Vertebral Malformation is an autosomal recessive inherited disorder in Holstein breed. It causes intra-uterine mortality through entire gestation period leading to repeat breeding and involuntary culling of cows and thereby the economic losses (Bergland et al., 2004). The DNA was amplified by using primers described by Yathish et al., (2011) and showed $287 \mathrm{bp}$ band size PCR product (Fig. 1). The amplified PCR product was digested with PstI restriction enzyme for 4 hours at 37 ${ }^{\circ}$ c. It showed the two fragments of size 264 and 23 bp size (Fig. 2). However, 23 bp band size is to small so it isinvisible.

The PCR products of SLC35A3 gene of all DNA samples were analyzed and showed the 287 bp size as per Yathish et al., (2011). The digested product showed the two bands of 264 and 23 bp size. In normal animals the RFLP pattern of SLC35A3 gene produces two fragments of size 264 and $23 \mathrm{bp}$, three fragments of 287, 264 and $23 \mathrm{bp}$ in carrier animals, whereas only one fragment of $287 \mathrm{bp}$ in homozygous recessive animals. It indicated that the studied all animals were wild type allele for SLC35A3 gene. 
Fig.1 Amplification of SLC35A3 gene

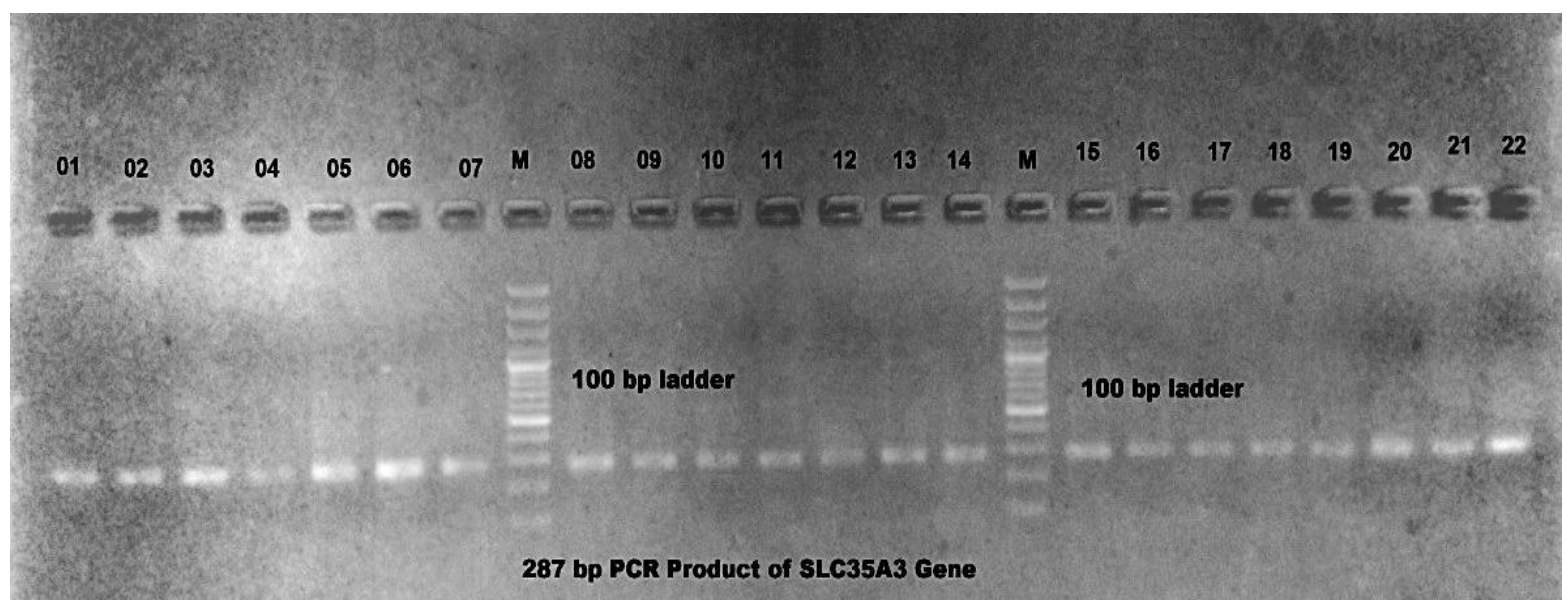

Fig.2 RFLP of SLC35A3 gene

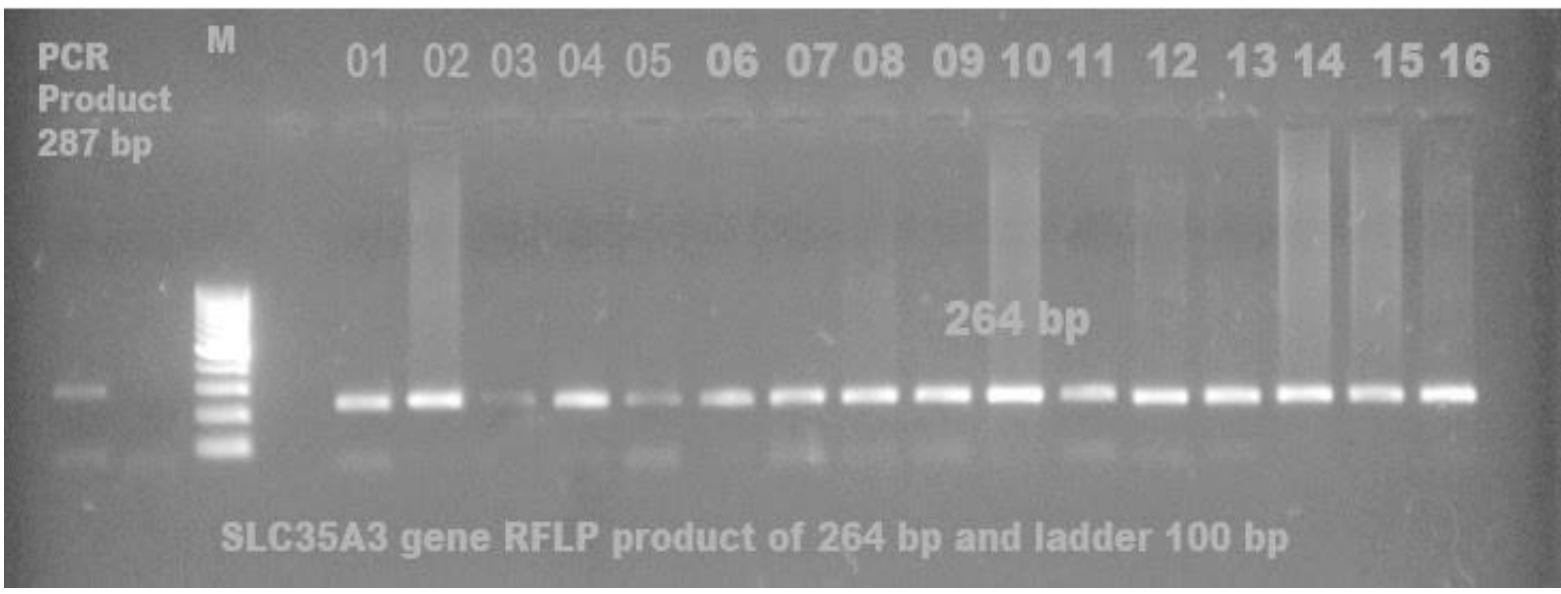

\section{Acknowledgment}

The authors are thankful to the Associate Dean, Bombay Veterinary College, Mumbai, Maharashtra, India, for providing essential facilities to carry out this research work.

\section{References}

Bergland, B.A. Person and H. Stalhammer (2004) Effects of complex vertebral malformation of fertility in Swedish Holstein cattle. Acta. Veterinaria Scandinavica. 45: 161-165.
Revell, S., (2001) Complex vertebral malformations in a Holstein calf in the UK. Vet Rec., 149: 659- 660.

Steffen, D. (2001) Complex vertebral malformations threaten Holstein herds. Vet Pract News, pp: 36

Yathish, H.M. Sharma, Ashwani Vijay Kumar Jain, Asit Chakraborty, D. Avtar Singh Tantia, M.S (2011) Genetic polymorphism of SLC35A3 gene in Karan Fries bull calves. The Indian journal of animal sciences 81(9): 951953. 


\section{How to cite this article:}

Khade, S.B., M.P. Sawane, V.D. Pawar, M.M. Chopade, R.D. Deshmukh and Komatwar, S.J. 2018. Study of Complex Vertebral Malformation in Repeat Breeder and Anoestrous Cows. Int.J.Curr.Microbiol.App.Sci. 7(08): 139-142. doi: https://doi.org/10.20546/ijcmas.2018.708.017 